\title{
BATIK PEKALONGAN CATALOG DEVELOPMENT WITH AUGMENTED REALITY TECHNOLOGY APPLICATION FOR CREATIVE ECONOMY IMPROVEMENT
}

\section{Ahmad Faisal Choiril Anam FATHONI ${ }^{*}$, Maryani MARYANI ${ }^{2}$, Satrya MAHARDHIKA ${ }^{3}$, and Javier Mahsa WIRAUTAMA ${ }^{4}$}

${ }^{1}$ Animation Program, Visual Communication Design School of Design, Bina Nusantara, Indonesia ${ }^{2}$ Information Systems Department, School of Information System, BINUS Business School Undergraduate, Indonesia

${ }^{3,4}$ Animation Program, Visual Communication Design School of Design, Bina Nusantara University, Indonesia

1'anam.fathoni@binus.ac.id; ${ }^{2}$ yanie@binus.edu; ${ }^{3}$ smahardhika@binus.edu; ${ }^{4}$ javier.wirautama@binus.ac.id

\begin{abstract}
In facing the influx of foreign products, the traditional fashion industry needs a way to survive. One of them is by using Augmented Reality technology. The Fitting Room Device Creativity Training Program with Augmented Reality media for the MSME Forum Community and Small and Medium Industries, is a form of activity for Binus University's School of Design and School of Information System community which aims to share knowledge and improve the insight and skills of the 2021 Batik MSME community. This training is intended for residents of the 2021 Batik UMKM Community. Most of their entrepreneurs are business owners of various types of commodities. It is hoped that after participating in this training, residents can display their superior products nationally or globally. Thus, it is also expected to be able to boost the existence and socio-economic and cultural progress of the MSME community in 2021. The scope of the material in this paper includes insight into how the influence of Augmented Reality can become a trend that can be used to support business development products such as Batik which is one of Indonesia's important assets.
\end{abstract}

Keyword: Augmented Reality, Batik Pekalongan, Small and Medium Industries, and Creative Industry

\section{BACKGROUND}

Through the power of creativity, the positive energy of individuals, communities, and nations can achieve the expected level of progress. The MSME Forum Community and the Batik Small Industry 2021, still require sustainable development, in general, people do not really understand the importance of design creativity in a package. Therefore, it is important to make efforts to empower it through various coaching programs which are assumed to be able to achieve social transformation and increase the role of technology so as to be able to balance the role of the market in the offline field. a populist economy based on packaging design. The 2021 Batik MSME Forum Community. Through various creative developments in packaging design, it is hoped that the socio-economic progress of the MSME Forum Community and the 2021 Batik Small and Medium Industry will be able to establish itself as a populist economic force in Indonesia.

In Indonesia, almost every region has its batik motif. However, there are three cities in Indonesia known as Batik City and batik centers, one of them namely Pekalongan City [1]. Batik has been designated as Indonesian Cultural Heritage, an intangible cultural heritage by the United Nations Educational, Scientific and Cultural Organization (UNESCO) on October 2, 2009. Batik is the art of drawing on cloth for clothing. This drawing art is not just drawing, but what motifs are drawn also has a philosophical meaning. The philosophy of this batik motif is closely related to Javanese culture, which is very thick with symbols that are deeply rooted in the philosophy of life of the Javanese people. Batik is an issue in Indonesian cultural identity stating two reasons; First, there is a collective awareness among Indonesian citizens to wear Batik because Batik is the ancestral heritage of the Indonesian nation. Second, Batik has a uniqueness and uniqueness that distinguishes the Indonesian nation from other nations [2]. Batik sales on the island of Java in 2018 were around $34 \%$, the highest compared to other areas. This phenomenon shows that Batik from the island of Java is in great demand by the community and shows the number of Batik industrial centers on Java. However, this sale is for batik printing which is sold at a lower price than written Batik. In Indonesia, there are several types of Batik based on the manufacturing technique, namely written Batik, painted Batik, and stamped Batik. The difficulty of making Batik makes the price of Batik expensive. Written Batik, for example, is sold from one million to tens of millions. Seeing this phenomenon and the conditions of globalization, it is not uncommon for other countries to make Batik a comedy. Like China, Thailand, and Malaysia, they invaded the market by doing Batik printing. Even local players do batik printing so that the written batik market is eroded by the presence of printing batiks which are much cheaper. Indeed, the written batik segment has its segment. Generally, batik consumers are collectors and generally understand Batik. According to the Solo Batik entrepreneur, people do not appreciate culture, especially Batik's artistic works passed down for generations. The largest written batik market share is in Jakarta, while most written Batik is in the Central Java area, one of which is in Pekalongan [3]. Based on this phenomenon, it is necessary to visualize written Batik presented differently using AR technology to get a different experience and see visualized batik products without having to go to a batik shop so that it is expected to attract buying interest.

The results of previous findings regarding batik that the delivery of 3-dimensional visualization information using augmented reality technology is a medium for delivering information that can provide visualization of the shape of batik with its motifs in more detail following actual 
conditions [4]. Increasing students' interest in learning about local wisdom, especially about batik, is integrated into Augmented Reality-based device technology [5]. Using a vertex marker in the MarkerBased Augmented Reality application, Batik Tulis artisans do not need to draw batik motifs with a pencil on the fabric because the batik motifs are directly displayed on the surface of the fabric by the application, so it is expected to reduce the time of the manufacturing process[5]. However, from some discoveries made, the application of AR has not been seen in the online marketing of batik handicrafts. If this can be realized, it will undoubtedly positively impact the development of the Batik creative industry in Indonesia and provide a different experience for consumers.

MSMEs or "LIKRIK" batik craftsmen are batik artisans, the majority of whom are hand-drawn batik. Currently, Perjain only uses a catalog of images presented only in the form of static visualization. So that consumers find it difficult to see the desired product in detail and more informative. Constraints experienced by "Likrik" batik craftsmen, some of the products purchased by consumers are not as expected, for example, the size or size is not appropriate, the batik results received are not in line with expectations. So, this batik craftsman needs to create a catalog that is visualized using augmented reality technology.

Various efforts to foster design creativity will be carried out by the Binus University Jakarta School of Design team for the 2021 MSME Forum Community residents. The scope of the guidance includes material on the importance of fitting rooms with the Augmented Reality method, which can be a means and solution for offline business users. It is essential to harmonize and support more optimally the potential they have previously, namely in Batik products. In essence, the design creativity training can provide significant added value to the potentials that have been previously owned. Through this training, it is hoped that the critical role of design aspects in various efforts to empower MSME participants in 2021 will be better understood by the community members. The activity begins with a briefing session on what and how design science plays a daily activity. This session includes an introduction to the essential elements of design in a package and how these elements play a role in shaping aesthetic values that correlate and can construct and represent the character and identity of a brand/brand from their products.

In the next activity, training was conducted to provide knowledge about visual identity and excellent and attractive packaging. This knowledge is essential because it can equip them to recognize, realize, and optimize the potentials that exist in their MSME Forum community. Furthermore, they are expected to implement it into the patterns of product promotion and sales practice strategies that have been and/or will be managed and produced. Such debriefing is also accompanied by various ongoing training regarding the creativity of other supporting skills. The training is carried out collectively through the direct active participation method of the participants. The session consists of several stages, such as briefing, discussion, and practice. Because it is still in a 'pandemic' condition, this activity is carried out online. Participants through the video 'zoom application' will discuss several existing cases to 'surge' the problem and then provide analysis and design solutions. The process of transferring knowledge by learning by doing is hoped that doing this will provide a more robust understanding for the participants. It is hoped that this activity can be continued by discussing other packaging visual problems.

In applying Augmented Reality to introduce Pekalongan batik to the Millennial generation, we use Design Thinking to answer the problems faced by MSMEs that produce Pekalongan batik. Several steps are applied in design thinking.

According to [6] IDEO and Stanford School methodologies are very similar, consisting of a series of iterative steps, using these stages to guide what should be focused on at any given time and iterating through them as needed:

1. Inspiration - The leading word for this step is empathy, which focuses on observing people in their natural context to trigger insights;

2. Synthesis - Consists of processing the information gathered in the first step, allowing the designer to dilute the research into actionable frameworks through abductive reasoning, making inferences based on observed user behaviors. It follows a similar logic.

3. Ideation and Experimentation - refers to developing educated solutions guided by previously established frameworks. It is how designers present and test rapidly assembled prototypes of imagined solutions to users or personas inspired by them. Similar to the Scandinavian strategies of organizational games and collaborative prototyping

4. Implementation: This is the final step in which a project road map is established, the design is refined, and the product/service is shipped for use by the final users.

In the first step, Inspiration, we use references based on the application of Augmented Reality technology in several fields, especially retail.

For the second step, Synthesis, we made observations about the problems faced by Batik Pekalongan entrepreneurs, such as how to develop a more comprehensive business and be known by the general public, especially the Millennial generation. Traditional fashion.

In the third step, Ideation and Experimentation, we develop several alternatives to find related solutions to the problems contained in the second step. One of the things that allow them to increase their appreciation \& interest in Batik Pekalongan is applying the latest technology to try it instantly; today, we are using augmented reality. 
In the fourth step, Implementation, we developed several alternative technologies related to augmented reality to choose a more straightforward but more effective technology to increase sales of Batik Pekalongan.

\section{DISCUSSION}

According to [7] consumer perceptions of the appearance and quality of $\mathrm{FaVs}$ in a VS (virtual and immersive virtual) were comparable to those in a physical store. The realistic representations of the FaVs in the VR environment, combined with users' visual and haptic interaction and immersive experience in the VR supermarket, may have deceived human senses, leading consumers to believe that what they see is what they will receive.

\section{CONCLUSION}

With the rapid development of Indonesia's fashion and textile industry, Pekalongan batik requires media to be known globally. One of the ways that can be used to bring consumers closer and increase their appreciation of Pekalongan batik is to use Augmented Reality. This technology can make it easier for the millennial segment, in particular, to try using this batik anytime without having to go to the boutique where the batik is located. With Augmented Reality, customers can choose when they use it in their respective homes directly. This research still really needs further development to be more interactive and adjust the movement of the customer.

\section{REFERENCES}

[1] Eki and Wie, "Batik: Momentum Mengangkat Para Pembatik," Kompas, Jakarta, p. 1, 03-Oct-2009.

[2] Iskandar and E. Kustiyah, "Batik Sebagai Identitas Kultural Bangsa Indonesia Di Era Globalisasi," Gema, vol. XXX, no. 52, pp. 2456-2472, 2017.

[3] M. Rosyada, "Strategi Survival Umkm Batik Tulis Pekalongan Di Tengah Pandemi Covid-19 (Studi Kasus Pada 'Batik Pesisir' Pekalongan)," Banco, vol. 2, pp. 69-93, 2020.

[4] K. Dede, H. Kusuma, I. K. A. Purnawan, N. Kadek, and D. Rusjayanthi, "Aplikasi Augmented Reality Informasi Corak Endek Bali pada Platform Android," vol. 6, no. 1, pp. 25-34, 2018.

[5] E. T. Tosida, A. D. Walujo, D. Ardiansyah, and Y. Yuliani, "Media Belajar Batik Berbasis Teknologi Augmented Reality," PROCEEDING Univ. PAMULANG, vol. 1, no. 1, 2018.

[6] J. H. De Oliveira, "FROM TINKERING METHODS TO DESIGN THINKING: PRIMORDIAL THOUGHTS IN DESIGN RESEARCH," no. August, pp. 5-8, 2019, doi: 10.1017/dsi.2019.398.

[7] C. Lombart, E. Millan, J. Normand, A. Verhulst, B. Labb, and G. Moreau, "Effects of physical, nonimmersive virtual, and immersive virtual store environments on consumers' perceptions and purchase behavior," vol. 110, no. December 2019, 2020, doi: 10.1016/j.chb.2020.106374. 